\title{
Organisering på tværs af organisatoriske grænser
}

\author{
Af Louise Brøns Kringelum*
}

\section{Resumé}

Værdiskabelse sker i stigende grad på tværs af organisatoriske grænser og skaber dermed grundlag for gentænkning og innovation af eksisterende forretningsmodeller. Der eksisterer derfor et behov for at gøre op med det traditionelle fokus på enkeltstående forretningsmodeller i isolerede organisationer. I denne artikel introduceres en distinktion mellem intra- og inter-organisatoriske forretningsmodeller. Ved at bygge bro mellem forskellige teoretiske dimensioner af interorganisatorisk samarbejde og forretningsmodellitteratur diskuteres, hvorledes forretningsmodelinnovation kan være en tilgang til at skabe organisering på tværs af organisatoriske grænser. Dette eksemplificeres gennem en case, der følger inter-organisatorisk samarbejde omkring forretningsmodeludvikling og etablering af en kollaborativ forretningsmodel på Aalborg Havn.

\section{Emneord:}

Forretningsmodeller, inter-organisatorisk samarbejde, værdiskabelse

*) Louise Brøns Kringelum er adjunkt, ph.d. ved Institut for Økonomi og Ledelse på Aalborg Universitet. 


\section{A. Introduktion}

\section{Baggrund}

I takt med at viden som en ubegrænset, kompleks størrelse er blevet et centralt konkurrenceparameter i værdiskabelse, foregår innovation ikke længere blot inden for de fysiske grænser af den enkelte organisation (Fjeldstad et al., 2012). Organisatoriske grænser er blevet amorfe (Wilden et al., 2018), og værdiskabelse sker derfor i stigende grad på tværs af organisationer gennem inter-organisatorisk samarbejde (Le Pennec and Raufflet, 2016). Dette forudsætter radikal gentænkning af de konkurrencemæssige strukturer, som former forståelsen af værdiskabelse, og de forudsætninger, dette skaber for organisering både i og mellem organisationer. Denne gentænkning inkluderer et brud med den traditionelle industrielle produktionstankegang baseret på skarp opdeling mellem organisationer i værdikæder, til i højere grad at forstå værdiskabelse som et fænomen, der opstår i værdinetværket i og omkring organisationer (Allee, 2000). Derved skabes et behov for organisering på tværs af organisatoriske grænser og innovation af eksisterende forretningsmodeller.

\section{Formål}

I indeværende artikel udfoldes mulighederne og udfordringerne ved at rekonfigurere værdiskabende processer gennem forretningsmodelinnovation. Det er efterhånden en anerkendt forståelse, at forretningsmodeller ikke kan isoleres inden for organisatoriske grænser (Amit \& Zott 2015; Zott, et al., 2011). Derfor forudsætter innovation af forretningsmodeller i højere grad inklusion af interessenter (Spieth et al., 2014), eksempelvis igennem åbne forretningsmodeller (Giesen et al., 2010) og samarbejde gennem netværksetablering (Storbacka et al., 2012). Processerne omkring, hvordan en sådan form for inklusion og samarbejde kan og bør forløbe, er imidlertid et overset emne indenfor eksisterende forskning i både forretningsmodel- og organisationsteori (Miller et al., 2014; Spieth et al., 2016). Med udgangspunkt i en konceptualisering af samarbejde som en organisationsteoretisk udfordring afspejler denne artikel eksisterende og potentielle sammenhænge med strømninger inden for forskningen i forretningsmodeller. Dette uddybes med et specifikt fokus på kollaborativ forretningsmodelinnovation, hvilket eksemplificeres i en case omkring interorganisatorisk samarbejde på Aalborg Havn.

\section{B. Teoretisk grundlag}

\section{Inter-organisatorisk samarbejde}

Inter-organisatorisk samarbejde er ikke et nyt fænomen, og det har længe været anerkendt, at organisationer kan ikke anskues som enkeltstående enheder, der opererer uden interaktion med øvrige aktører i værdinetværk. I 1930'erne fremhævede Barnard (1938), at organisationer basalt set er et resultat af samarbejde, til dels med et individfokus, men samtidig også ud over de eksisterende 
organisatoriske rammer. Barnards forståelse af organisationer var baseret på en inklusion af en lang række interessenter herunder investorer, leverandører, kunder etc., som tidligere var blevet anset som stående uden for de organisatoriske grænser. Med afsæt i disse organisationsteoriske tanker og udviklingen af stakeholderteorien (Freeman, 1984) er det i dag anerkendt, at organisationer ikke kan anskues isoleret fra deres værdinetværk. Organisationer er åbne systemer, som er i kontinuerlig interaktion med hinanden og omgivet af usikkerhed (Thompson, 1967). En måde at håndtere denne usikkerhed er ved at skabe relationer mellem systemerne, eksempelvis gennem inter-organisatorisk samarbejde.

Inter-organisatorisk samarbejde har mange facetter, hvorfor der ikke findes nogen entydig definition af konceptet. Både de inter-organisatoriske relationer og samarbejde som organisatorisk fænomen rummer en kompleksitet, som betyder, at de i sammenhæng skaber et koncept, der rummer en flerhed af betydninger.

At der eksisterer forbindelser mellem organisationer (inter-), var grundtanken bag Porters klassiske værdikædetænkning (1985). Oprindeligt medvirkede Porters værdikædeforståelse til et øget fokus på vertikal integration mellem organisationer. Men denne værdikædeforståelse kommer i stigende grad til kort, da værditilbuddet i de enkelte organisationer bliver dematerialiseret, hvorved de både fysiske og lineære strømme i værdikæden opløses (Breuer and Lüdeke-Freund, 2017). Kompleksiteten bag den værdiskabelse, der finder sted i den enkelte organisation, er blevet forøget og udgør ikke længere blot den fysiske transaktion af produkter, services og omsætning, men i højere grad også viden og immaterielle aktiver (Allee, 2000). Med afsæt i denne forståelse af værdiskabelse, fungerer organisationer i dag i større værdinetværk, som skaber økonomisk værdi gennem komplekse dynamiske interaktioner af både materiel og immateriel natur (Allee, 2000).

På samme vis kan samarbejde, ifølge Wood og Gray (1991:146) defineres ved, at en gruppe af uafhængige interessenter $i$ et problemdomæne tager del i en interaktiv proces ved at anvende delte regler, normer og strukturer til at handle eller træffe beslutninger omkring problemstillinger relateret til dette domæne. Denne definition afspejler centrale aspekter af samarbejde, herunder at organisationerne, som indgår i samarbejde, vedbliver at være selvstændige enheder i deres eksisterende form. Inter-organisatoriske enheder som eksempelvis partnerskaber, alliancer og netværk repræsenterer rent diskursivt de relationer, som er blevet etableret mellem de deltagende organisationer (Cropper et al., 2008). De forskellige former for relationer, som etableres, er derfor centrale for at forstå den inter-organisatoriske enhed i sin helhed bestående af forskellige enkeltstående enheder. Den proces, der foregår, når relationerne mellem enkeltstående organisationer etableres, har som fremhævet af definitionen af Gray \& Wood (1991) til formål at resultere i handlinger eller beslutninger. Iboende i denne definition er derfor anerkendelsen af, at 
samarbejde ikke er betinget af selve opnåelsen eller indfrielsen af de forventede handlinger eller beslutninger.

Inter-organisatorisk samarbejde kan forstås som en proces, der opstår, når organisationer interagerer med henblik på at etablere nye organisatoriske former eller nye sociale strukturer (Thomson et al. 2009: 23). Den teoretiske udvikling af samarbejde som et koncept for organisering er baseret på strømninger fra både organisationsøkonomi og organisationsteori (Parmigiani and Rivera-santos, 2011). Organisationsøkonomisk repræsenterer inter-organisatorisk samarbejde en valgmulighed på et kontinuum, der bevæger sig mellem internalisering og markedsbaseret organisering (Parmigiani and Rivera-santos, 2011). Valget mellem organiseringsform er i denne teoretiske verden baseret på den mest efficiente styringsform med hensyn til at generere øget overskud i organisationen, inspireret af eksempelvis transaktionsomkostningsteori, ressourcebaseret teori, knowledge-based view, dynamiske kapabiliteter og agentteori (Parmigiani and Rivera-santos, 2011). Organisationsteoretisk vurderes muligheden for inter-organisatorisk samarbejde ud fra, hvornår organisationer mere effektivt kan udføre deres aktiviteter gennem interorganisatoriske og interpersonelle relationer. Baseret på ressourceafhængighedsteori, stakeholderteori, institutionel teori samt social netværksteori er der derfor et større fokus på de sociale strukturer og relationer i samarbejde. De økonomiske og organisatoriske teoretiske strømninger afspejler forskellige perspektiver på organisering af samarbejde, som skønt de ikke repræsenteret en universel teori, understreger en flerhed af de nuancer, som bør fremhæves, når organisering transcenderer traditionelle organisatoriske grænser.

\section{Forskellige dimensioner af inter-organisatorisk samarbejde}

Når vi på dansk anvender begrebet samarbejder, fungerer det som en paraplybetegnelse, der udvisker en del af nuancerne, som findes i de forskellige dimensioner af inter-organisatorisk samarbejde. Eksempelvis repræsenterer cooperation og collaboration, som begge på dansk ofte oversættes til samarbejde, forskellige grader af integration mellem de samarbejdende organisationer. Cooperation anvendes ved et samarbejde om et fælles formål, hvor den enkelte virksomhed har mulighed for relativt klart at adskille sine respektive mål og målsætninger, da processen er simpel og resultatet er målbart og deleligt. Collaboration afspejler derimod en proces baseret på indre motivation og tillid, hvor mindst to organisationer samarbejder med henblik på at opnå gensidigt fordelagtige resultater (Miles et al., 2005). Formålet for den enkelte organisation samt kompleksiteten af samarbejdet repræsenterer derfor centrale dimensioner til nuancering af interorganisatorisk samarbejde som koncept.

Der eksisterer en flerhed af taksonomier, som kategorisere samarbejdsformer baseret på yderligere parametre eksempelvis: retslig organisering, position i værdikæden, funktionelt formål, størrelse, rækkevidde (Child et al. 2005: 113). Tilsammen udgør disse forskellige parametre, som samarbejde 
kan defineres ved. Derfor kan samarbejde også antage mange forskellige former herunder; alliancer, joint ventures, vertikale leverandørrelationer, franchises, krydssektorale partnerskaber eller netværk (Parmigiani \& Rivera-Santos 2011) afhængig af de tidsmæssige forventninger, graden af organisering samt formålet med samarbejdet.

a) De tidsmæssige forventninger er centrale, når der arbejdes med inter-organisatorisk samarbejde, og er derfor tæt forbundet med både graden af organisering og formålet med samarbejdet. Samarbejdet kan initieres på baggrund af både kort- eller langsigtede forventninger. Samarbejde etableres som et middel til at nå et mål, og på trods af det ofte store strategiske arbejde, der kan ligge i at etablere inter-organisatorisk samarbejde, kan dette også omfatte kortsigtede målsætninger som eksempelvis tilegnelse af nye kompetencer og viden fra partnere eller deslige (Child et al. 2005).

b) Formålet med samarbejdet afspejler de drivkræfter, der findes i den enkelte organisation for at indgå i en samarbejdsproces. Overordnet set kan disse drivkræfter opdeles som: 1 . legitimitetsorienterede -, 2. kompetenceorienterede -, 3. ressourceorienterede -, og 4. samfundsorienterede samarbejdsmotiver (Gray \& Stites 2013). Disse samarbejdsmotiver henviser til, hvad der driver den enkelte organisation i processen mod at etablere interorganisatorisk samarbejde. Derudover afhænger tilgangen til samarbejde gennem forretningsmodelinnovation af formålet med selve samarbejdet. Ifølge (Child, Faulkner and Tallman, 2005) kan formålet med samarbejde opdeles ved henholdsvis læringsrelationer og kompetencesubstituering.

c) Graden af organisering afspejles i det formaliseringsbehov, som ligger til grund for samarbejdet. Som Williamson (1985) i sin fortolkning af transaktionsomkostningsteorien fremsatte, findes der mange hybridformer mellem hierarki og marked, som repræsenterer mindre systemiske former for organisering. Dette afhænger af graden af integration og formalisering mellem organisationer, som kan baseres på et miks af markedsinteraktion i form af transaktioner og bureaukratisk integration (Todeva and Knoke, 2005).

\section{Fem dimensioner af organisatorisk samarbejde}

Der findes imidlertid adskillige yderligere dimensioner, som er nødvendige af undersøge, både på intra- og inter-organisatoriske niveauer, når det handler om at skabe forståelse for processen omkring etablering af inter-organisatorisk samarbejde. Samarbejde etableres ifølge Thomson and Perry (2006) igennem fem dimensioner, som kontinuerligt genforhandles i løbet af samarbejdsprocessen på baggrund af den læring, som aktørerne opnår jævnfør tabel 1. De fem dimensioner af samarbejde repræsenterer henholdsvis strukturelle, agency og social kapital orienterede aspekter af samarbejdsprocessen, som alle skal være afbalancerede. 


\begin{tabular}{|c|c|}
\hline $\begin{array}{l}\text { Styring (Governance) } \\
\text { Afstemning af hvordan der træffes beslutninger omkring de overordnede } \\
\text { rammer for samarbejdet såvel som strukturer for beslutningstagning }\end{array}$ & \multirow{2}{*}{$\begin{array}{l}\text { Strukturelle } \\
\text { dimensioner }\end{array}$} \\
\hline $\begin{array}{l}\text { Administration } \\
\text { Etablering af et operationelt system af strukturer f.eks. } \\
\text { koordineringsmekanismer med fokus på implementering og styring af } \\
\text { målopnåelse }\end{array}$ & \\
\hline $\begin{array}{l}\text { Organisatorisk autonomi } \\
\text { Balancering af de separate virksomhedsidentiteter og den fælles } \\
\text { samarbejdsidentitet, herunder de iboende selv-interesser og de kollektive } \\
\text { interesser }\end{array}$ & $\begin{array}{c}\text { Agency } \\
\text { dimension }\end{array}$ \\
\hline $\begin{array}{l}\text { Gensidighed } \\
\text { Baseret på enten delte eller forskellige interesser skal samarbejdsparterne } \\
\text { opleve gensidig fordelagtighed i den indbyrdes afhængighed }\end{array}$ & \multirow{2}{*}{$\begin{array}{l}\text { Social kapital } \\
\text { dimensioner }\end{array}$} \\
\hline $\begin{array}{l}\text { Normer } \\
\text { Herunder gensidighed og tillid i samarbejdet hvilket ofte er forbundet med } \\
\text { temporalitet, da tillid etableres over tid og gentagne interaktioner }\end{array}$ & \\
\hline
\end{tabular}

Tabel 1: Fem dimensioner af samarbejde

Kilde: Baseret på Thomson et al. (2009) og Thomson \& Perry (2006) gengivet fra Kringelum (2017)

Som afspejlet i ovenstående tabel forudsætter en samarbejdsproces mellem organisationer, at der i de strukturelle dimensioner og agency dimensionen skabes rammer for koordinering gennem alignment og tilpasning både af den enkelte organisation og samarbejdsenheden som en helhed. Samtidig skal der skabes kooperation som afspejlet i de social kapitale dimensioner gennem engagement, forpligtelse og en etablering af gensidighed (Gulati, Wohlgezogen and Zhelyazkov, 2012). Graden af koordinering og kooperation og dermed vigtigheden af de fem forskellige dimensioner afhænger af den valgte samarbejdsform.

Graden af samarbejde omfatter samtidig, hvorvidt den eksisterende værdiskabelse i de enkelte organisationer påvirkes. Dette afspejles i, hvorvidt samarbejdet vil bevirke forandring af de eksisterende forretningsmodeller eller etablering af nye kollaborative forretningsmodeller. Dette forretningsmodelperspektiv på inter-organisatorisk samarbejde uddybes i de følgende afsnit.

\section{Intra- og inter-organisatoriske forretningsmodeller}

De sidste 20 år har forretningsmodellen markeret sig som et både teoretisk og praktisk koncept. Konceptet har rødder fra både strategi, iværksætteri og innovationslitteraturen (Gassmann et al., 2016). Denne multi-teoretiske baggrund har medført en del uklarhed omkring, hvad en 
forretningsmodel egentlig er, og hvordan konceptet kan bidrage både i den teoretiske udforskning, men også i forretningsudvikling i praksis. Trods uklarhederne har forretningsmodelkonceptet medvirket til at samle en flerhed af perspektiver i strategic management (Ritter and Lettl, 2017).

I den eksisterende forskning anskues forretningsmodellen ofte som et organisationsspecifikt, men alligevel grænseoverskridende aktivitetssystem (Zott, Amit and Massa, 2011). Ifølge Shafer et al. (2005) kan en forretningsmodel forstås som “... a representation of a firm's underlying core logic and strategic choices for creating and capturing value within a value network". Specielt for denne definition er ekspliciteringen af, at værdiskabelse og -indfangelse ikke kan anskues isoleret fra det værdinetværk, som organisationer befinder sig i. Relationen mellem forskellige forretningsmodeller ved individuelle organisationer afspejles imidlertid sjældent eksplicit i eksisterende forskning. Derfor fokuseres der primært på enkeltstående forretningsmodeller i isolerede organisationer (Mason and Spring, 2011). Som også afspejlet i ovenstående definition, er værdiskabelse et centralt begreb i forretningsmodellitteraturen. Fremfor at fokusere på værditilbuddet i form af services og produkter, centreres fokus på den oplevede kundeværdi, der skabes i organisationen (Storbacka et al., 2012). I takt med at værdikæder nedbrydes og værditilbuddet dematerialiseres (Breuer and Lüdeke-Freund, 2017), kan forretningsmodellen derfor ikke isoleres til den enkelte organisation.

Selvom forretningsmodeller primært analyseres med udgangspunkt i den enkelte virksomhed, har der de sidste 10 år været et spirende fokus på, hvad det kræver at skabe forretningsmodeller, som overskrider organisatoriske grænser. I 2006-2007 blev dette koncept beskrevet af Miles et al. (2006) og Chesbrough \& Schwartz (2007) som henholdsvist kollaborativt iværksætteri (collaborative entrepreneurship) og samudviklingspartnerskab (co-development partnerships). Siden da er adskillelige begreber kommet til, som alle betegner forskellige måder at skabe værdi gennem organisering på tværs af organisatoriske grænser eksempelvis koblet open innovation, hvor to eller flere partnere målrettet organiserer vidensstrømme på tværs af organisatoriske grænser gennem fælles opfindelser og kommercialisering af aktiviteter (Chesbrough \& Bogers 2014: 19), netvoerksbaseret voerdisamskabelse (networked value co-creation Nenonen and Storbacka, 2010) samt kollaborativ forretningsmodelinnovation (collaborative business model innovation Laudien and Daxböck, 2015; Kringelum, 2017).

Fælles for disse betegnelser er, at de indebærer en grad af innovation af forretningsmodeller både intra- og inter-organisatorisk. Derfor præsenteres i det efterfølgende den rolle, forretningsmodellen som locus for innovation, spiller i inter-organisatorisk samarbejde. 


\section{Forretningsmodelinnovation som en tilgang til organisering på tværs}

Forretningsmodelinnovation omfatter en forandring af forretningslogikken i en organisation (Schneider, Spieth and Clauss, 2013), som skaber nye rammer for at skabe værdi og indfange værdi for organisationens interessenter (Casadesus-Masanell and Zhu, 2013).

Når organisationer skal skabe værdi på tværs af organisatoriske grænser, forudsætter det, at der etableres en stærk, sammenhængende forretningsmodel, som ekspliciterer både værdiskabelses- og værdiindfangelsesprocesserne. Når værdi skal samskabes, forudsætter det derfor kompatibilitet mellem forretningsmodellerne i værdinetværket (Nenonen and Storbacka, 2010). Værdiskabelse i samarbejde hænger derfor uløseligt sammen med et fokus på innovation i samarbejde, da der uvægerligt vil ændres på de værdiskabende logikker i de implicerede organisationer. Men innovationen bør, som diskuteret ovenfor, række ud over organisatorisk innovation med henblik på at sikre eksplicit værdiskabelse i samarbejdsprocessen. Dette kan organiseres gennem kollaborativ forretningsmodelinnovation.

De adskillige dimensioner, der eksisterer til kategorisering af samarbejde, er interessante, når det kommer til definition af, hvorledes værdiskabelse kan ske gennem organisering på tværs af organisatoriske grænser, som en art meta-organisering. Dette er relevant, da etableringen af kollaborativ forretningsmodelinnovation ikke blot forudsætter gængs forretningsmodelinnovation, men samtidig også organisatorisk innovation med henblik på at sikre gensidig læring (Heikkilä and Heikkilä, 2013). Hvorvidt samarbejdet etableres med henblik på at skabe læringsrelationer eller kompetencesubstituering (Child, Faulkner and Tallman, 2005) påvirker direkte den grad af forretningsmodelinnovation, samarbejdet forudsætter. Eksempelvis vil et samarbejde med fokus på eksisterende viden og co-exploitation af eksisterende aktiviteter være mindre omfattende, og derved kræve mindre tilpasning af den eksisterende forretningsmodel. Derimod vil en kollaborativ proces funderet i co-exploration gennem ny viden potentielt stille krav til både tilpasning af den eksisterende og etablering af nye, kollaborative forretningsmodeller (Parmigiani and Rivera-santos, 2011). Hertil kommer desuden de tilhørende tidsmæssige forventninger og graden af formalisering i organisering, som derfor er relevante parametre at inddrage. Derfor bør der ved initiering af kollaborativ forretningsmodelinnovation skabes en balance mellem fokus på den operationelle innovation af forretningsmodellen som en materiel, aktivitetsbaseret konceptualisering af værdiskabelsen, og kognitiv innovation som forståelsen af den eksisterende værdiskabelse, de separate organisationer, og den fælles værdisamskabelse i relation til eksisterende forståelse (Kringelum 2017).

Kollaborativ forretningsmodelinnovation kan derfor forstås som en egenskab af en interorganisatorisk enhed, der skabes gennem en proces, hvor uafhængige organisationer rekonfigurerer 
eksisterende eller genererer ny værdi-(sam)-skabelse eller værdi-(sam)-indfangelse ved at innovere de materielle og kognitive aspekter af interaktion (Kringelum, 2017).

Anerkendelsen af, at samarbejde kan medvirke til at skabe og indfange værdi, er baseret på den ressource-orienterede tilgang i strategic management (Hamel, 1991; Duschek, 2004). En af faldgruberne ved denne tilgang er imidlertid, hvordan den konkurrencemæssige fordel, der kan skabes gennem samarbejdet, kan tilknyttes den inter-organisatoriske enhed, som er etableret. Når den konkurrencemæssige fordel eller værdiskabelse forbliver tilknyttet en enkelt organisation, tilsidesættes en del af potentialet i den inter-organisatoriske relation og de ressourcer, som indgår i denne relation (Dyer and Singh, 1998; Duschek, 2004). Derfor er opnåelsen af fælles værdiindfangelse på baggrund af samarbejde fortsat en stor udfordring i inter-organisatorisk sammenhæng (Ritala et al., 2013). Det er derfor problematisk, at eksisterende forskning ofte afspejler selve etableringen af samarbejde som den ultimative målsætning. Derved tilsidesættes den potentielle eller faktiske værdiskabelse, som bør drive processen og dermed opnåelsen af de succesfaktorer, som eksisterer for samarbejdet (Le Pennec and Raufflet, 2016). Dette forøger dermed risikoen for, at samarbejdet i sidste ende ikke resulterer i hverken værdiskabelse eller indfangelse (Le Pennec and Raufflet, 2016).

Som præsenteret i det foregående kan inter-organisatorisk samarbejde etableres gennem kollaborativ forretningsmodelinnovation med forskellige grader af organisering. En sådan proces præsenteres i nedenstående case, som omhandler et samarbejde mellem organisationen Aalborg Havn og en lokal logistikvirksomhed.

\section{Case: Samarbejde i Den Intelligente Havn}

\section{Caseintroduktion}

Aalborg Havn er den femte største industrihavn i Danmark og organiseret som en kommunalt ejet aktieselskabshavn. Derfor har Aalborg Havn siden omlægningen til aktieselskabshavn i 2000 fokuseret på at sikre et kontinuerligt udviklingspotentiale for virksomhederne, der er lokaliseret i og omkring havneområdet. I 2013 påbegyndte Aalborg Havn en strategiudviklingsproces med henblik på at blive "Den Intelligente Havn" (Krabbe and Holstein, 2015). Dette strategiske initiativ var funderet i et ønske om at gentænke de organisatoriske roller, som havne traditionelt bestrider, og derved skabe grobund for en fremtidig konkurrencemæssig fordel ved proaktivt at etablere en mere forretningsorienteret logik i den traditionelt set aktivtunge havnesektor. Den strategiske udvikling var drevet af ambitionen om at blive "Stoerk på logistik og samarbejde" for at sikre fremtidig vækst både i organisationen og regionaløkonomisk. 
Aalborg Havns strategiudviklingsproces var funderet $i$ erkendelsen af, at havnes forretningsmodeller er udfordrede (Kringelum 2019). Traditionelt set har havne fungeret som logistik-hubs, men grundet en øget forventet som selvstændig værdiskabelse er havnes rolles under en markant forandring (Paixão and Marlow, 2003). Udover at varetage den myndighedsmæssige regulering af havnerummet samt forestå operatørrelaterede serviceopgaver og udlejning af arealer og ejendomme, forventes det i stigende grad, at havne varetager kommercielt orientede logistikopgaver og aktivt skaber havnerelaterede netværk gennem etablering af relationer mellem havneaktører (Flynn, Lee and Notteboom, 2011; Lee and Lam, 2016). Dette skaber en forventning om radikalt ændrede værdiskabelsesprocesser i havneorganisationer. At facilitere denne værdiskabelse skaber behov for nye kapabiliteter i havneorganisationer, hvilket ansporede Aalborg Havn til i deres strategiudviklingsproces at sætte fokus på, hvorledes partnerskaber kunne understøtte forandringen af deres eksisterende forretningsmodel.

\section{Samarbejdsprocessen}

I vinteren 2013 initierede Aalborg Havn en møderække med en lokal logistikvirksomhed, som var placeret på havneområdet. Formålet med denne møderække var at afdække virksomhedernes roller på havnen, da de på forskellig vis indgik i adskillelige forsyningskæder på tværs af havnesystemet. I nogle tilfælde udbød de substituerende services baseret på sammenfald i materielle aktiver. Dette forretningsområde var imidlertid under pres drevet af en omkostningsminimerende adfærd gennem forsyningskæden. Derfor stod Aalborg Havn og logistikvirksomheden overfor lignende udfordringer; hvordan skulle deres fremtidige forretningsmodeller udvikle sig?

Han kan heller ikke fortælle mig, hvad hans fremtidige forretningsmodel skal være. Det er det, jeg godt kan lide ved ham, for det kan jeg heller ikke med havnen. Men jeg kan bare fortælle, at den ikke skal være, som den er nu. Og for at gøre det, så er jeg nødt til at samle mig med nogle andre partnere.

CEO Aalborg Havn

Møderækken strakte sig over en fireårig periode med halvårlige møder, hvor forskere fra Aalborg Universitet faciliterede mødeaktiviteter mellem de deltagende virksomheder. De første møder blev derfor indledt med et fokus på at opnå en forståelse for de forretningsmodeller, som eksisterede i begge virksomheder. Formålet med dette var at skabe et fundament for at udvikle deres forretningsmodeller i fællesskab for at sikre fremtidig konkurrencedygtighed.

\section{Koblede forretningsmodeller}

Selvom der eksisterede visse sammenfald mellem aktiviteterne og ressourcerne, der lå til grund for værdiskabelsen i virksomhederne, var der markant forskel på deres forretningsmodeller. Mens Aalborg Havn udelukkende udbød sine services til virksomheder i og omkring havnesystemet, 
fungerede logistikvirksomheden som en international aktør på markedet for logistikløsninger. På baggrund af de identificerede sammenfald af forretningsmodeller i relation til aktiviteter på havneområdet, fandt de to virksomheder det interessant at undersøge muligheden for ressourcedeling af sammenlignelige materielle aktiver. Rationalet bag dette initiativ var dels et fokus på omkostningsreducering mellem virksomhederne, men samtidig også et fokus på, hvorledes de i fællesskab kunne servicere virksomhederne i og omkring havnesystemet mere optimalt.

Igennem tættere koordinering mellem virksomhederne formåede de at kombinere deres aktiver, primært transport- og løftemateriel, og derved skabe yderligere grobund for øvrige logistikaktiviteter hos både fælles og fremtidige potentielle kunder. Dette samarbejde affødte dermed ikke en forandring af den eksisterende værdiskabelse i de separate virksomheder, men åbnede derimod op for en større rækkevidde af potentielle kunder sideløbende med en omkostningsreduktion internt i begge virksomheder. Dermed repræsenterede denne samarbejdsform primært kompetencesubstituering (Child, Faulkner and Tallman, 2005) gennem en horisontal sammensmeltning af aktiviteter og materielle ressourcer. Derved koblede virksomhederne deres forretningsmodeller tættere sammen gennem operationel koordinering.

Ressourcedelingsaktiviteterne blev formaliseret gennem en samarbejdskontrakt med henblik på at minimere risikoen for opportunistisk adfærd fra begge virksomheder, og samtidig skabe grobunden for en videre udvikling af samarbejdsinitiativerne. Selve omfanget af dette samarbejde varierede fra projekt til projekt og var dermed drevet af selve markedstransaktionen. Men gennem det etablerede ressourcedelingssamarbejde opnåede Aalborg Havn og logistikvirksomheden også en indsigt i, hvorledes interaktionen på tværs af havnesystemet influerede på de iboende værdiskabelsesprocesser og de udfordringer, som i øjeblikket påvirkede disse. Herunder hvor meget omkostningsminimering og dertilhørende suboptimering samt personlige relationer påvirkede udfaldet af forhandlinger og den afhængighed, som eksisterede mellem virksomheder på havneområdet.

Det er de samme organisatoriske og menneskelige modstandsformer, vi møder alle sammen. (..) Noget af det er frygt, fordi man er bange for at miste sin forretning, noget andet det er, fordi man er bange for ikke at være dygtig nok, eller at man bliver afsløret. Eller man bliver afhængig af det. Det der med at sige, man er nødt til at gøre sig afhængig, det vigtige er at finde ud af, hvem du vil være afhængig af. Du kan ikke diskutere, om du bliver afhængig af noget, fordi der er ingen af vores systemer, der kan ses alene.

CEO Aalborg Havn 


\section{En kollaborativ forretningsmodel}

Erfaringerne fra det operationelle samarbejde omkring ressourcedeling afspejlede en markant grad af indbyrdes afhængighed mellem virksomhederne i havnesystemet, som blev fastlåst grundet den omkostningsminimerende natur og manglende tillid mellem virksomhederne. Derfor fortsatte Aalborg Havn og logistikvirksomheden i møderækken med at diskutere, hvorledes de kunne ændre på selve strukturen af værdinetværket, hvori de indgik som en del af selve havnesystemet. Målsætningen med dette var af afdække, hvorvidt virksomhederne havde mulighed for i højere grad at samarbejde omkring værdiskabelse ved at håndtere nogle af de logistiske udfordringer, som begge virksomheder oplevede $\mathrm{i}$ havnesystemet. Ved at samarbejde om dette, ville logistikvirksomheden kunne opnå en større legitimitet til at varetage udvidede opgaver i havnesystemet, mens Aalborg Havn ville kunne tilgodese en samfundsdrevet motivation om større vækst i havnesystemet.

Derfor påbegyndte virksomhederne en produktudviklingsproces med henblik på at udfordre de eksisterende normer i havnesystemet. I praksis ville de gennemføre dette ved at udvikle en logistikløsning, der kunne håndtere nogle af de transportmæssige udfordringer, som eksisterede på havneområdet. På baggrund af ønsket om at håndtere de oplevede logistikudfordringer $\mathrm{i}$ værdinetværket på Aalborg Havn, blev produktudviklingsprocessen funderet i en diskussion af det fælles værdiskabelsespotentiale, der kunne eksistere i en kollaborativ forretningsmodel. En sådan forretningsmodel ville eksisterer i tværsnittet mellem virksomhederne, og dermed forudsætte nytænkning af værditilbud, aktiviteter, kunderelationer etc. uden forankring i den enkelte virksomheds eksisterende forretningsmodeller.

Denne samarbejdsproces var i højere grad end det indledende ressourcedelingssamarbejde baseret på den vertikale fordeling af aktiviteter i forsyningskæderne gennem havnesystemet, der muliggjorde indsigt i forskellige værdiskabende processer for både Aalborg Havn og logistikvirksomheden. Samtidig var denne samarbejdsproces baseret på en læringsrelation, fokuseret på at innovere den eksisterende struktur i værdinetværket. Derfor omfattede denne proces i højere grad innovation af de kognitive strukturer omkring både de eksisterende forretningsmodeller og den potentielle kollaborative forretningsmodel, da produktudviklingen ville forudsætte, at virksomhederne antog nye roller i havnesystemet. Som afspejlet i citatet fra logistikvirksomheden nedenfor forudsatte dette, at de øvrige virksomheder i værdinetværket også er forberedt på at indgå i og acceptere forandringen der var iboende i produktudviklingen:

Der skal man lige finde ud af, hvad der både er godt for os selv og de virksomheder. For hvis de ikke synes, det er fedt, så er det ligegyldigt.

CEO Logistikvirksomhed 
Et sådant projekt ville tidsmæssigt have et langt scope og dermed forudsætte en større grad af formalisering, kontrolsystemer samt en fælles identitet, som blev opfattet som legitim i havnesystemet. Det værdiskabelsessystem, som skulle bygges op, udfordrede de strukturelle dimensioner af samarbejdet. Hvordan og hvornår i processen skulle kunderne kontaktes? Og hvordan kunne der genereres en indtægt? Samt det omfattende spørgsmål om, hvorledes en eventuel profit skulle deles for at sikre co-capturing af værdien? Trods de kollektive interesser og gensidigheden, viste det sig vanskeligt at skabe en samarbejdsidentitet mellem virksomhederne. I løbet af 2016 udviklede virksomhederne i fællesskab en konceptuel logistikløsning, som kunne afhjælpe de oplevede udfordringer i havnesystemet. Denne løsning blev dog aldrig sat i produktion, og samarbejdsprocessen blev kort efter afsluttet.

\section{Analyse og konklusioner med kollaborativ forretningsmodelinnovation}

Når værdiskabelse transcenderer organisatoriske grænser, skabes nye præmisser for organisering i det 21. århundrede. Forretningsmodeller bliver mere komplekse, og interaktionen mellem virksomheder i værdinetværk skaber rammen for, hvordan værdiskabelse kan gentænkes.

Som afspejlet gennem artiklen kan forretningsmodelkonceptet medvirke til at skabe gensidighed gennem indsigt i de forretningsmodeller, potentielle samarbejdspartnere bringer med i samarbejdet. Hvad enten der fokuseres på at koble eksisterende forretningsmodeller tættere sammen som cooperation eller etablere nye forretningsmodeller i collaboration, vil en oplevet gensidighed i samarbejdet være centralt.

Casen om Aalborg Havn repræsenterer en samarbejdsproces, som havde til hensigt at skabe kollaborativ forretningsmodelinnovation. Aalborg Havn ønskede igennem samarbejdet at rekonfigurere både den eksisterende værdiskabelse tilknyttet deres forretningsmodeller, men samtidig også at udvikle et potentiale for værdiskabelse, der strakte sig ud over de eksisterende aktiviteter i organisationen. Selvom virksomhederne ikke lykkedes med at gennemføre produktudviklingsprocessen, kan det dog ikke kategoriseres som, at samarbejdet mislykkedes. Som fremhævet af Wood and Gray (1991) er samarbejde ikke betinget af målopnåelse. Den interaktive proces mellem aktørerne i henholdsvis Aalborg Havn og logistikvirksomheden afspejlede imidlertid flere interessante aspekter af strukturer og normer, som influerer på, hvordan kollaborative forretningsmodeller kan udvikles, samt hvad forretningsmodelkonceptet kan understøtte samarbejdsprocesser.

Forretningsmodelinnovation kan forstås som en tilgang til at forsøge at etablere værdiskabelse på tværs af organisatoriske grænser. Men at skabe værdi gennem inter-organisatorisk samarbejde er 
en kompleks proces, som forudsætter inddragelse af centrale interessenter for at sikre et både intraog inter-organisatorisk konfigurationelt fit mellem både nye og eksisterende forretningsmodeller (Nenonen and Storbacka, 2010). Kompleksiteten i denne proces gør det vanskeligt at sætte på formel, da denne vil afhænge af parametre som eksempelvis relationer på tværs af værdinetværket, de institutionaliserede normer og den indbyrdes ressourceafhængighed. Sammenspillet mellem disse parametre kan influere på udfaldet af en samarbejdsproces, og dermed hvorvidt det vil lykkedes for virksomheder sammen at overskride de organisatoriske grænser og etablere kollaborativ forretningsmodelinnovation.

\section{Referencer}

Allee, V. (2000) 'Reconfiguring the Value Network', Journal of Business Strategy, 21(4), pp. 36-39. Barnard (1938) The Functions of the Executive. Cambridge, Massachusetts: Harvard University Press.

Breuer, H. and Lüdeke-Freund, F. (2017) 'Values-Based Network and Business Model Innovation', International Journal of Innovation Management, 21(3), pp. 1-35.

https://doi.org/10.1142/s1363919617500281

Casadesus-Masanell, R. and Zhu, F. (2013) 'Business Model Innovation and Competitive Imitation: The Case of Sponsor-based Business Models', Strategic Management Journal, 34, pp. 464-482. https://doi.org/10.1002/smj.2022

Chesbrough, H. and Bogers, M. (2014) 'Explicating Open Innovation: Clarifying an Emerging Paradigm for Understanding Innovation', in Chesbrough, H., Vanhaverbeke, W., and West, J. (eds) New Frontiers in Open Innovation. Oxford University Press, pp. 3-28.

https://doi.org/10.1093/acprof:0so/9780199682461.003.0001

Chesbrough, H. and Schwartz, K. (2007) 'Innovating Business Models with Co-Development Partnerships', Research Technology Management, 50(1), p. 55.

https://doi.org/10.1080/08956308.2007.11657419

Child, J., Faulkner, D. and Tallman, S. (2005) Cooperative Strategy Managing Alliances, Networks, and Joint Ventures. 2nd edn. Oxford: Oxford University Press.

Cropper, S. et al. (2008) 'Introducing Inter-organizational Relations', in The Oxford Handbook of Inter-organizational Relations. Oxford University Press, pp. 3-21.

https://doi.org/10.1093/oxfordhb/9780199282944.003.0001

Duschek, S. (2004) 'Inter-Firm Resources and Sustained Competitive Advantage', Management Review, 15(1), pp. 53-73. https://doi.org/10.5771/0935-9915-2004-1-53

Dyer, J. H. and Singh, H. (1998) 'The Relational View: Cooperative Strategy and Sources of Interorganizational Competitive Advantage', Academy of Management Review, 23(4), pp. 660-679. https://doi.org/10.5465/amr.1998.1255632 
Fjeldstad, Ø. D. et al. (2012) 'The Architecture of Collaboration', Strategic Management Journal, 33, pp. 734-750. doi: 10.1002/smj.

Flynn, M., Lee, T. and Notteboom, T. (2011) 'The next step on the port generations ladder: Customer-centric and community', in Notteboom, T. (ed.) Current Issues in Shipping, Ports and Logistics. Brussels: Academic and Scientific Publishers, pp. 497-510.

Freeman, R. E. (1984) Strategic management: A stakeholder approach. Edited by Pitman. Boston. Gassmann, O., Frankenberger, K. and Sauer, R. (2016) Exploring the Field of Business Model Innovation. Springer.

Giesen, E. et al. (2010) 'When and how to innovate your business model', Strategy \& Leadership, 38(4), pp. 17-26. https://doi.org/10.1108/10878571011059700

Gulati, R., Wohlgezogen, F. and Zhelyazkov, P. (2012) 'The Two Facets of Collaboration:

Cooperation and Coordination in Strategic Alliances', Academy of Management Annals, 6, pp. 531583. https://doi.org/10.1080/19416520.2012.691646

Hamel, G. (1991) 'Competition for Competence and Inter-Partner Learning Within International Strategic Alliances', Strategic Management Journal, 12(Summer), pp. 83-103. https://doi.org/10.1002/smj.4250120908

Heikkilä, M. and Heikkilä, J. (2013) 'Collaborative Business Model Process for Networked Services Innovation', in International Conference on Electronic Commerce. Berlin: Heidelberg: Springer, pp. 133-147. https://doi.org/10.1007/978-3-642-39808-7_12

Krabbe, P. and Holstein, C. (2015) Den intelligente havn - the intelligent port. En foranderlig havn en havn i bevægelse. Edited by A. H. A/S. Aalborg.

Kringelum, L. B. (2017) Transcending Organizational Boundaries: Exploring intra- and interorganizational processes of business model innovation in a port authority. Aalborg University.

Kringelum, L.B. (2019). 'Reviewing the challenges of port authority business model innovation', World Review of Intermodal Transportation, Vol. 8, No. 3, pp. 265-291.

https://doi.org/10.1504/writr.2019.102371

Laudien, S. and Daxböck, B. (2015) 'Antecedents and Outcomes of Collaborative Business Model Innovation', in The XXVI ISPIM Conference. Hungary: Budapest.

Lee, P. T.-W. and Lam, J. (2016) 'Developing the Fifth Generation Ports Model', in Dynamic Shipping and Port Development in the Globalized Economy. Volume 2: Emerging Trends in Ports. Palgrave Macmillan, pp. 186-210. https://doi.org/10.1057/9781137514233_8

Mason, K. and Spring, M. (2011) 'The sites and practices of business models', Industrial Marketing Management. Elsevier Inc., 40(6), pp. 1032-1041.

https://doi.org/10.1016/j.indmarman.2011.06.032

Miles, R. E., Miles, G. and Snow, C. C. (2005) Collaborative entrepreneurship: How communities of 
networked firms use continuous innovation to create economic wealth. Stanford CA: Stanford University Press. https://doi.org/10.1016/j.pursup.2007.06.001

Miles, R. E., Miles, G. and Snow, C. C. (2006) 'Collaborative entrepreneurship: A business model for continuous innovation', Organizational Dynamics, 35(1), pp. 1-11.

https://doi.org/10.1016/j.orgdyn.2005.12.004

Miller, K., McAdam, M. and McAdam, R. (2014) 'The changing university business model: a stakeholder perspective', R \& D Management, 44(3), p. 265. https://doi.org/10.1111/radm.12064

Nenonen, S. and Storbacka, K. (2010) 'Business model design: conceptualizing networked value cocreation', International Journal of Quality and Service Sciences, 2(1), pp. 43-59.

https://doi.org/10.1108/17566691011026595

Osterwalder, A. and Pigneur, Y. (2010) Business model generation: a handbook for visionaries, game changers, and challengers. Hoboken, NJ: John Wiley \& Sons. https://doi.org/10.1111/j.1540$\underline{5885.2012 .00977 \_2 . x}$

Paixão, A. C. and Marlow, P. B. (2003) 'Fourth generation ports - a question of agility?', International Journal of Physical Distribution \& Logistics Management, 33(4), pp. 355-376. https://doi.org/10.1108/09600030310478810

Parmigiani, A. and Rivera-santos, M. (2011) 'Clearing a Path Through the Forest: A Meta- Review of Interorganizational Relationships', Journal of Management, 37(4), pp. 1108-1136.

https://doi.org/10.1177/0149206311407507

Le Pennec, M. and Raufflet, E. (2016) 'Value Creation in Inter-Organizational Collaboration: An Empirical Study', Journal of Business Ethics. Springer Netherlands, (March), pp. 1-18.

https://doi.org/10.1007/s10551-015-3012-7

Porter, M. E. (1985) Competitive Advantage. Free Press.

Ritala, P. et al. (2013) 'Value creation and capture mechanisms in innovation ecosystems: a comparative case study', International Journal of Technology Management, 63(3/4), pp. 244-267. https://doi.org/10.1504/ijtm.2013.056900

Ritter, T. and Lettl, C. (2017) 'The wider implications of business-model research', Long Range Planning. Elsevier Ltd, pp. 1-8. https://doi.org/10.1016/j.lrp.2017.07.005

Schneider, S., Spieth, P. and Clauss, T. (2013) 'Business model innovation in the aviation industry', International Journal of Product Development, 18(3/4), p. 286.

https://doi.org/10.1504/ijpd.2013.055010

Shafer, S. M., Smith, H. J. and Linder, J. C. (2005) 'The power of business models', Business Horizons, 48(3), pp. 199-207. https://doi.org/10.1016/j.bushor.2004.10.014

Spieth, P., Schneckenberg, D. and Matzler, K. (2016) 'Exploring the linkage between business model (\&) innovation and the strategy of the firm', R\&D Management, 46(3), pp. 403-413. 
Spieth, P., Schneckenberg, D. and Ricart, J. E. (2014) 'Business model innovation - state of the art and future challenges for the field', R\&D Management, 44(3), pp. 237-247.

https://doi.org/10.1111/radm.12071

Storbacka, K. et al. (2012) 'Designing Business Models for Value Co-Creation', Review of Marketing Research, 9(June), pp. 51-78.

Thompson, J. D. (1967) Organizations in Action. New York: McGraw-Hill.

Thomson, A. M. and Perry, J. L. (2006) ‘Collaboration Processes: Inside the Black Box', Public Administration Review, 66, pp. 20-32. https://doi.org/10.1111/j.1540-6210.2006.00663.x

Thomson, A. M., Perry, J. L. and Miller, T. K. (2009) ‘Conceptualizing and measuring collaboration', Journal of Public Administration Research and Theory, 19(1), pp. 23-56.

https://doi.org/10.1093/jopart/mum036

Todeva, E. and Knoke, D. (2005) 'Strategic alliances and models of collaboration', Management Decision, 43(1), pp. 123-148. https://doi.org/10.1108/00251740510572533

Wilden, R. et al. (2018) 'Revisiting James March (1991): Whither exploration and exploitation', Strategic Organization, In Press(20/03/18). https://doi.org/10.1177/1476127018765031

Williamson, O. E. (1985) The economic intstitutions of capitalism: Firms, markets, relational contracting. New York: Free Press.

Wood, D. J. and Gray, B. (1991) 'Towards a Comprehensive Theory of Collaboration', Journal of Applied Behavioral Science, 27(2), pp. 139-162.

Zott, C., Amit, R. and Massa, L. (2011) 'The business model: Recent developments and future research', Journal of Management, 37(4), pp. 1019-1042.

https://doi.org/10.1177/0149206311406265 